\title{
院内製剂硫酸アトロピン散の含量均一性*1
}

\author{
鈴木一市, 鈴木時紀, 石川安信, 川影逸郎, 藤井喜一郎 \\ 浜松医科大学医学部附属病院薬剤部*2
}

\section{Content Uniformity of Atropine Sulfate Powders Prepared in Hospital Pharmacy*1}

\author{
KAZUICHI SUZUKI, TOKINORI SUZUKI, YASUNOBU ISHIKAWA, \\ ITSURO KAWAKAGE, KIICHIRO FUJII \\ Pharmacy of Hamamatsu University School of Medicine Hospital*2
}

(Received December 21, 1981)

\begin{abstract}
In the preparation of $0.1 \%$ atropine sulfate powder, the effect of the method of preparation on mixing degree, distribution of particle size and component in different particle size was studied by three different methods using tartrazin as a model. Solution mixing method (SMM) as compared with powder dilution method (PDM) and combined method of SMM and PDM, though the component in different particle size was different, gave a good mixing degree which showed small variance at various sampling weight. Distribution of the component in SMM was affected by material or volume of binder. All the particles in granules which passed through 42-mesh sieve and remained on 200-mesh sieve maintained the $90-110 \%$ content when $10 \%$ water was used as binder in SMM. Furthermore, packaging procedure had little effect on content uniformity of the powder prepared by SMM and PDM. SMM, if the component in the different size fraction was checked, proved to be a very good method in the preparation of the powders with very low content of active ingredient in hospital pharmacy. Thus $0.1 \%$ atropine sulfate powder with good content uniformity was obtained by SMM.
\end{abstract}

Keywords _ atropine sulfatepowder; granulation; degree of mixing; content uniformity; distribution of component in different size fraction

\section{は じめに}

硫酸アトロピン（以下 At と略）の経口剂は，一般に 100 倍あるいは 1000 倍の散剤として調剂に用いられる。

At のように非常に少量の主薬を大量の薬品に分散させ た散剤を院内で調製する場合, 調阂のしやすさよりも主 薬の混合度に注意し, 主薬の混合法, 賦形剤の種類, 主 薬を溶液状態で混合する溶媒法での溶液の種類および量 等の要因が品質にどう影響するかを把握した上で調製す ることが望ましい。

*1 第13回日本病院薬羭師会東海ブロック学術大会(名 古屋, 1980年) で発表.

*2 浜松市半田町 $3600 ; 3600$, Handa-cho, Hamamatsu-shi, 431-31 Japan
ジゴキシン錠の製法の検討結果から,1) 溶媒法の 散 剂 は主薬を段階的に希釈する倍散希釈法の散剂より混合度 が良好であり，造粒されて細粒状になるため取り扱いが 容易になると思われる.乙かし，この造粒された散昘は 種々の大きさの粒子が混合された状態であるから，打錠 用造粒品と同じように, 乾燥時の薬品の移動等により各 大きさの粒于中の薬品の含量すなわち粒子径別含量が異 なる場合がある. ${ }^{2}$ このような散剤は調剂時に分級が起 こると服用量に過不足を生じる.

著者らはモデル薬品としてタートラジンを選び, 製法 と品質の関係を混合度や粒度ばかりでなく造粒法で調製 した散剤では粒子径別含量からも調査し, その結果に基 ついて良好な1000倍の At 散を製剤化できたので報告す る. 


\section{実 験 の 部}

\section{1. 試 料}

着目成分としてタートラジン（以下 Y-4と略, 和光純 薬) および At (J.P.), 希釈成分として結晶乳糖（以下 CLと略), 粉末乳糖 (以下 PLと略), 結合剤として水お よびバレイショデンプン(J.P.)の 5 \%水溶液を用いた. 各成分の物性を Table 1 に示す.

2. 1000 倍散の調製（仕込量 $1 \mathrm{~kg}$ )

1）倍散希釈法（以下 TTと略）：PLに60メッシュ で節過した Y-4 を加え，万能混合䚌汼㙨(以下混合機と 略, 品川工業製, 5DMr)で混合 (63 rpm, 10 分間) して 500倍散とし次にCLを加えてさらに10分間混合し1000倍 散とする。

2）溶媒法：Y-4を仕込量の10および 20\%の水に溶解 した液を結合剂として CL に加え混合機で揘和 $(63 \mathrm{rpm}$, 5 分間) 乙, 笠過 $\left(12\right.$ ×ッシュ) $\rightarrow$ 乾燥 $\left(60^{\circ} \mathrm{C}\right) \rightarrow$ 節過 (32×ッシュ) $\rightarrow$ 乾燥 $\left(60^{\circ} \mathrm{C}\right)$ したGW-10および GW-20 と $1 \%$ の水に溶解した Y-4を CLに加え混合 (63rpm, 1 分間）した後， $5 \%$ デンプン水溶液を $20 \%$ 加え捏和 (63 $\mathrm{rpm}, 5$ 分間）し以下 $\mathrm{GW}$ と同様に操作した GS-20の 2 法により調製した。

3） 1)および2)の併用による調製法(以下 GT と略)： 2) の溶媒法の GS-20 に準じて100倍散（以下 G-100 と 略）を調製した後，CL を加兄て混合（63rpm, 5 分間） し1000倍散とする.

\section{3. 測定方法}

1）安息角：コニシ FK 型安息角測定器を用いた。 2) 粒度分布：各散剂 $20 \mathrm{~g}$ を電磁式ミクロ形ふるい振とう器 (筒井理化器)で $32,40,60,80,100,150,200$ メッシ

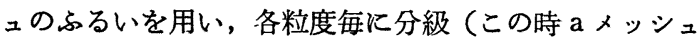
を通過しbメッシュにとまる粒度を $\mathrm{a} / \mathrm{b}$ と略）し, 重量
を測定した．3）粒子径別含量：2)で分級した各粒子径 の粒子約 $0.5 \mathrm{~g}$ を精科し, Y-4は水に溶解して $428 \mathrm{~nm}$ の 吸光度を測定した．Atは J.P.IX の注射液に準じてフ タル酸水素カリウム緩衝液（pH 5.6）飞溶解し，ブロム クレゾールグリーン・ $\mathrm{NaOH}$ 試液, 水およびクロロホル ムを加え振とら後, クロロホルム層をとり $416 \mathrm{~nm}$ で吸 光度を測定した４） 1 包中の含量：各散剤を15 g 科量 し, コニシ式自動分包機 (727-K10 型でスリット幅を $1 / 2$ および $1 / 4$ にて 30 包に分割分包 $(0.5 \mathrm{~g} /$ 包) した後 No. $1 ， 8 ， 16 ， 24 ， 30$ の 5 ホールの分包品について重量およ び含量を求め, これらの分包品の含量の変動係数（以下 $\mathrm{CV}$ と略）で分包時のバラッキを評価した。

\section{結果 と考寮}

\section{1. 前目成分としてY-4を用いた場合}

1）安息角および粒度

Table 1 に示すようにTTは安息角が $58^{\circ} \mathrm{C}$ ときく流 動性が悪いが,他の散斉は38-47C であり取り扱い上余 り支障はない，TT の粒度分布は PLと CLの粒度分布お よび混合割合から得られる値とほぼ同じである. GW お よび GS はいずれる 32/80メッシュの粒子径の粒度が CL より多くなり造粒されたことを示している. 特に GS は GWに比較して粒子が大きく $32 / 42$ メッシュの間に $37 \%$ も含まれている. GW と GS の粒度分布の差は結合剂に 用いた水とデンプン溶液のちがいであり，デンプン溶液 の方が結合力が大きく造粒されやすい，GT は CL より 大きな粒子を含む G-100と CL の 2 つの粒度分布の異な る散㶡の混合された系である．以上の結果から製法によ り種々の粒度の散剤が得られ溶媒法では造粒されて取り 扱い易い細粒刘となる。

2) 含量

調斉時に秤量する可能性のある 1 日常用量まで含量を

Table 1. Particle Size Distribution of Materials and Granules

\begin{tabular}{|c|c|c|c|c|c|c|c|c|c|}
\hline \multirow{2}{*}{ Sample } & \multicolumn{8}{|c|}{ Distribution of particle size $(z)$} & \multirow{2}{*}{$\begin{array}{c}\text { Angle of response } \\
\left({ }^{\circ}\right)\end{array}$} \\
\hline & $>32$ & $32 / 42$ & $42 / 60$ & $\begin{array}{l}60 / 80 \\
\quad \text { (mesh }\end{array}$ & 2) $80 / 100$ & $100 / 150^{\circ}$ & $150 / 200$ & $<200$ & \\
\hline $\mathrm{Y}-4, \mathrm{PL}, \mathrm{At}$ & & & & & & & 0 & 100 & - \\
\hline$C L$ & & & 0 & 8.7 & 33.2 & 35.0 & 13.2 & 9.9 & 41 \\
\hline TT & & & 0 & 4.6 & 17.0 & 20.2 & 12.7 & 45.4 & 58 \\
\hline $\mathrm{GW}-10$ & 0 & 9.3 & 21.6 & 24.3 & 18.6 & 15.6 & 7.1 & 3.5 & 47 \\
\hline GW-20 & 0 & 5.7 & 16.2 & 26.1 & 21.5 & 17.5 & 8.8 & 4.1 & 47 \\
\hline GS-20 & 0 & 36.6 & 27.5 & 14.4 & 8.5 & 7.0 & 3.3 & 2.7 & 42 \\
\hline G-100 & 0 & 11.9 & 26.2 & 23.5 & 16.4 & 14.9 & 4.8 & 2.1 & - \\
\hline GT & 0 & 0.8 & 2.3 & 15.0 & 31.6 & 29.5 & 13.7 & 7.1 & 38 \\
\hline
\end{tabular}


保障する必要があるとの観点から, At の常用量の $1.5 \mathrm{mg}$ の 1 日および14日分に相当するサンプリング量をるって 各散剂の Y-4含量のバラッキを調査した結果を Fig. 1亿 示した. $20 \mathrm{~g}$ の秤量時にはどの散剤でも含量の CVが 1 \%程度で製法間に差が認められない，しかし，1.5gの 時にはTT怙よびGTはCVがそれぞれ 3.3，7.5\%である のにGW怙よび GS は 0.5一1.9\%であり，明らかに溶媒 法で調製した散剤の方が含量のバラッキが小さい，溶媒 法の三者間では CVは変わらない.溶媒法を併用した GT に执いてCV が特に大きな原因は, 少量のサンプリング で 100 倍の散剤と CL とに分級した結果, 極端に混合度 が悪化したためと考えられる.

\section{3）粒子径別含量}

流動性が良く，粒度分布に幅のある散剤では詰替や調 剤中に分級を生ずることがある。すしこの分級した種々 の粒子径の粒子毎に含量が異なれば正確な投与を行らこ とができないそそこで粒子径別含量を測定した。なお TT は分級しにくいのでこの測定をする必要がなく除外 した.

Fig. 2 亿示すように造粒操作を行った散剤は, 各粒子

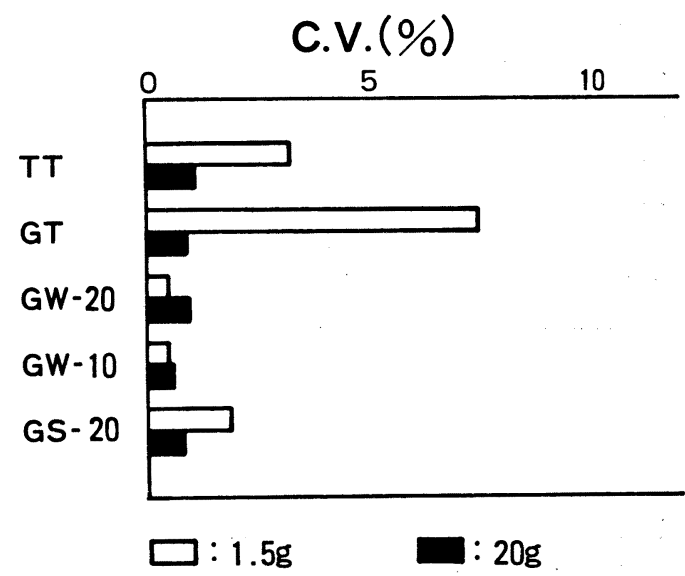

Fig. 1. Variation of Content by Weight of Granule for Dispensing

\section{4）分包品の含量}

1)〜3)の特性を有する散剂を分包した時に 1 包中の含 量がどのように変動するかを調査し，その結果を Table 2 飞示す。どの散剤む 1 包中の含量の $\mathrm{CV}$ は $8 \%$ 以上を 示し,スリット幅が $1 / 4$ の時は $1 / 2$ の時に比較して $3-7 \%$ 低 い値を示している。 この值は丹野らの報告3)之同様であ りかなり大きい。この CV は 1 包中の散剈の重量が大き く影響しているため，分包された重量に対する含量を算
径の粒子が同一含量を示すとはかぎらない.GSは60/200 メッシュの粒子中の Y-4の含量は 60 - $80 \%$ と低く, 32/42 メッシュの粒子では $112 \%$ と高い含量を示している. GW はGS に比較して極端に低含量の粒子は見られず，むし ろ GW-20のように130-150\%と含量の高い粒子が多い。 GW-10は 200メッシュより大きな粒子はすべて 90-110 \%の間にあり, 粒子径別含量のバラッキが最も小さく, たとえ分級してる正確な投与を行える．粒子径別含量の 変動には, この結果のよらに微粒子側で高含量を示す場 合と西村らのように低含量を示す2)場合がある.GTでは 32/60×ッシュの間の粒子はほとんどCLで希釈する前の G-100 のため含量が10倍にも達し80メッシュより小さい 粒子は $50 \%$ 以下と含量が低い。この散剂はG-100と CLの 2 剤の混合物と考えられ G-100の粒度が CL とあまりに あ異なるため粒子径別含量が最も悪い散剤になったと思 われる．したがって GTは分級により含量の均一性が最 も変化する危険性があり，GT法では100倍散と賦形剤の 粒度をそろえることが望ましい，以上の結果から同じ散 剤でありながら粒子径別含量の挙動が製法によって異な り本測定の重要性を示唆している。

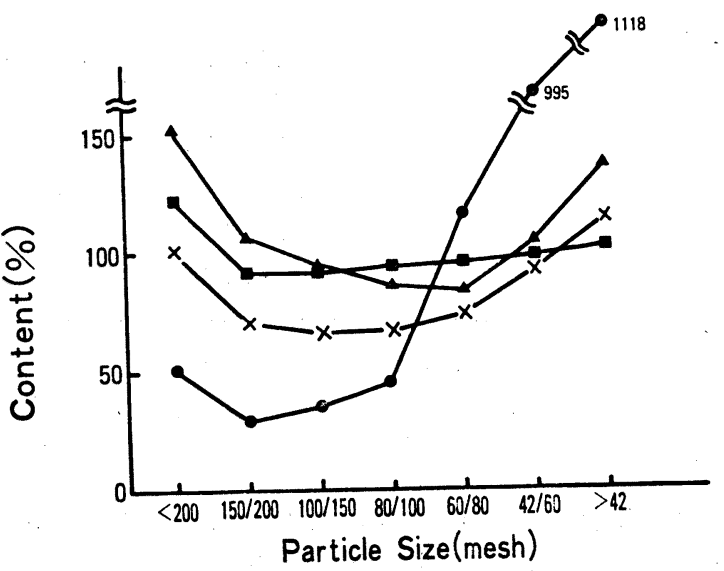

Fig. 2. Effect of Preparation Methods on Distribution of Tartrazine in Different Size Fractions of Granules

$$
\begin{array}{ll}
: \mathrm{GT} & \boldsymbol{\Delta}: \mathrm{GW}-20 \\
\times: \mathrm{GS}-20 & : \mathrm{GW}-10
\end{array}
$$

出しその CV を求めた結果,いずれのスリット幅でも 1.5 $\mathrm{g}$ サンプリングした時と同様に $\mathrm{GW}$ および $\mathrm{GS}$ が TT あ るいは GTより CVが小さく $1-2 \%$ である. GT は他の 散剤よりスリット幅の影響を受けやすく $1 / 4$ から $1 / 2$ に変え ると CVが3.5から6.1\%に上昇する.この現象には分級 による不均一化が関与していると思われる. 溶媒法の散 
剤で粒子径別含量の最も悪かった GS-20 は GT ほどこ の現象は起こっていない．もちろんこの現象には分級の しやすさと異常な含量を示す粒子の散剂中の含有率が関 係しているため, 粒子径別含量だけで分包品の含量の変 動を予測することはできない。

\section{2. 兼目成分として At 考用いた場合}

Yー4を着目成分として検討した結果，倍散希釈法は混 合度や取り扱いが溶媒法に比較して悪いため, At 散の 調製には GW-10に準じた溶媒法を採用した。

1000倍 At 散の製法（1 kg仕込）

At $1.0 \mathrm{~g}$ を100mlの水に溶解した液をCL中に添加し混 合機（スクリュービーダー翼， $63 \mathrm{rpm）で} 5$ 分間混合す る. $0.1 \%$ ブリリアントブルー・FCF $1.0 \mathrm{~g}$ を加えてさ らに 5 分間混合し, 12 ×ッシュ節過して $50^{\circ} \mathrm{C} て ゙$ 通風乾
Table 2. Variation of Content in Package by Preparation Methods of Tartrazine Granule

\begin{tabular}{cccccc}
\hline \multirow{2}{*}{ Granule } & C.V. 1$)$ & \multicolumn{3}{c}{ Content } & \multicolumn{3}{c}{ Converted content } \\
\cline { 3 - 6 } & Slit gap & $1 / 4$ & $1 / 2$ & $1 / 4$ & $1 / 2$ \\
\hline TT & 14.4 & 18.2 & 4.6 & 5.5 \\
GT & 8.0 & 11.2 & 3.5 & 6.1 \\
GW-20 & 10.4 & 16.5 & 1.4 & 1.8 \\
GW-1 0 & 10.2 & 17.6 & 1.6 & 1.1 \\
GS-20 & 11.3 & 16.4 & 1.4 & 1.3 \\
\hline
\end{tabular}

Packing method: $0.5 \mathrm{~g}$ granule in 1 package at 30 divisions with Konishi automatic packing machine (type 727-K 10)

燥する．次に 32 メッュで整粒した後恒量になるまで乾 燥して散剤とする。

Table 3. Quality of Atropine Sulfate Powder Prepared in Hospital Pharmacy

1) Distribution

\begin{tabular}{ccr}
\hline $\begin{array}{c}\text { Particle size } \\
\text { (mesh) }\end{array}$ & $\begin{array}{c}\text { Frequency } \\
(8)\end{array}$ & $\begin{array}{c}\text { Content } \\
(8)\end{array}$ \\
\hline 42 & 1.8 & 96.6 \\
$42 / 60$ & 9.6 & 101.1 \\
$60 / 80$ & 25.4 & 105.2 \\
$80 / 100$ & 27.4 & 96.9 \\
$100 / 150$ & 25.1 & 93.6 \\
$150 / 200$ & 8.5 & 95.3 \\
$<200$ & 2.3 & 115.8 \\
\hline
\end{tabular}

2) Content : $98.8 \%$

3) Angle of response : $47^{\circ}$
このAt散は，Table 3 に示したように粒度の規格か らは細粒剂であり取り扱いやすい，また，粒度別含量は 32/200メッシュまでの粒子の含量はいずれも90-110\%に あり各粒子中に At が均一に付着している. 以上の結果 から, 着目成分としてタートラジンを用いた時と同様に 溶媒法の GW-10 に準じた製法を用いると良好な品質の 散剂を調製できることがわかった。

\section{まとめ}

1. 混合度は，倍散希釈法より溶媒法で調製した散剤 の方が優れている。

2. 溶媒法の散昘は，粒度毎に含量が異なり，粒子径 別含量の挙動は製法に左右される. しかし, 著者らが調
製したどの散斉でも分包時の分級による含量変化はほと んど起こらなかった。

3. 造粒された散, 細粒剂については, 常用量での含 量試験ばかりでなく，粒子径別含量をチェックすること が望ましく, 混合度だけから安易に溶媒法を用いて院内 製剤を調製することは慎まなければならない。

\section{文嘀}

1）園部 尚, 蓮見俊士, 吉野 節, 小林洋二式, 川田 裕溢：薬剤学，37，216 (1977)。

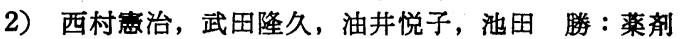
学, 38, 117 (1978).

3) 丹野慶紀, 長岡英世, 吉田慎一, 营原博道, 池田 䐵: 病院薬学, 6, 78 (1980). 